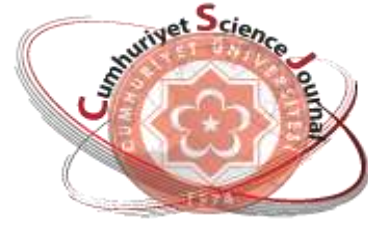

e-ISSN: $2587-246 X$

ISSN: 2587-2680

\section{Cumburiyet Seionee Journal $\operatorname{csj}$}

Cumhuriyet Sci. J., Vol.40-1(2019) 197-203

\title{
Comprehension of Road Traffic Signs by Various Road Users in Kano City Ibrahim Khalil UMAR* ${ }^{*}$, Samir BASHIR
}

Kano State Polytechnic, Department of Civil Engineering Technology, Kano, NIGERIA

\begin{abstract}
Human perception of the information on the road signs is a critical factor in determining the safe use of both the vehicle and the interacting environment. A total of 30 road traffic signs which includes10-warning, 10-regulatory and 10-informatory signs were evaluated using 190 questionnaires to determine comprehension level of road users in Kano. The questionnaire was administered to both private and commercial drivers of trucks, cars, tricycle, motorcycle, and bicycle. Majority of the respondents are male (91.6\%) which is due to the disproportionate ratio between male and female drivers in Kano city and $90 \%$ of them are youth below the age of 40 years showing that majority of the state drivers are young people. The comprehension level was found to be good $79 \%$. The least comprehended signs in Kano are "park and ride" with comprehension level of 54.7\%, followed by "Narrow bridge" (60\%), "line merge ahead" (62.1\%), "slippery road" (63.2\%), "No entry for all vehicles" (70.5\%). The signs with up to $90 \%$ recognition were "fuel station", "stop sign" and "school crossing". Sex, education, driving experience and type of vehicle used seems to affect the comprehension level of drivers in Kano. Truck drivers have a poor understanding of the traffic signs lower than all other classes of road users $(65 \%)$.
\end{abstract}

Keywords: Comprehension, road signs, driving experience.

\section{Kano Şehrindeki Çeşitli Yol Kullanıcıları Tarafından Yol Trafik İşaretlerininin Bilinirliği}

\begin{abstract}
Özet. Yol işaretlerinin insanlar tarafından algılanabilirliği hem araçların hemde etkileşimindeki çevrenin güvenilir olarak kullanılabilmesi için kritik bir faktördür. Bu çalışmada 190 anket kullanılarak Kano şehrindeki yol kullanıcılarının 10 adet uyarı, 10 adet trafik tanzim ve 10 adet trafik bilgi işareti olmak üzere toplam 30 trafik işaretini kavrama seviyeleri değerlendirilmiştir. Anketler hem şahsi hem de ticari kamyon, otomobil, triportör (üç tekerlekli bisiklet), motorsiklet ve bisiklet sürücülerine yöneltilmiştir. Kano şehrindeki erkek ve bayan sürücü orantısızlığına bağlı olarak ankete katılanların çoğunluğu erkektir $(91.6 \%)$ ve 90\%”ㄱ 40 yaşın altındadır, bu durum bölgedeki sürücülerin birçoğunun genç olduğunu göstermektedir. İşaretlerin bilinirlik seviyesi $79 \%$ olarak bulunmuştur. Kano'daki en az kavranan işaretler $54.7 \%$ bilinirlik seviyesi ile "Park et devam et" işaretidir. Bunu "Daralan köprü" (60\%), "İleride birleşen şerit" (62.1\%), "Kaygan yol" (63.2\%) ve "Araç giremez" (70.5\%) işaretleri takip etmektedir. Bilinirliği 90\%'a varan işaretler, "Benzin istasyonu”, Dur işareti" ve "Okul geçidi" dir. Cinsiyet, eğitim, sürüş tecrübesi ve kullanılan araç tipi Kano'daki sürücülerin işaretleri kavrama seviyelerini etkileyen parametreler olarak görünmektedir. Kamyon sürücüleri trafik işaretlerini diğer tüm sınıflardaki yol kullanıcılarından daha zayıf algılamaktadır (65\%).
\end{abstract}

Anahtar Kelimeler: Bilinirlik, yol işaretleri, sürüş tecrübesi. 


\section{INTRODUCTION}

Road signs, traffic lights, and other traffic control devices are used to regulate, warn, guide or inform road users. An acceptable level of road traffic quality and safety is achieved with the orderly and predictable movement of traffic and pedestrian, by helping drivers to be aware of the road condition ahead [1]. Human perception of the information on road signs is a critical factor in determining the safe use of both the vehicle and the interacting environment [2].

Research conducted in Canada and USA by Dewar, Kline, \& Swanson, (1994) using 480 volunteer licensed drivers evaluated age differences in comprehension of traffic sign symbols. The result shows that older drivers had poorer understanding than younger ones in $39 \%$ of the symbols examined. [3]

Unsatisfactory comprehension of traffic signs is a common problem for drivers in many countries. The unsatisfactory comprehension is related to the characteristics of the traffic control devices themselves. Research concerning traffic sign comprehension dates back to 1966 and that early studies focused on evaluating user understanding levels of local traffic signs and most of the results indicated that the general comprehension performance was far from satisfactory [4].

Generally, drivers have problems in comprehension of traffic control devices. Drivers' personal characteristics control drivers' comprehension abilities with educational background as a major factor affecting the understanding of traffic control devices [5]. The overall comprehension of the 15 traffic signs of the 202 respondents in Soloraya area, Central Java Province is $67 \%$ [6].

There is a serious problem in drivers' understanding of existing traffic signs. only 50$60 \%$ of the traffic signs were identified correctly by the drivers. However, drivers' years of education, gender, monthly income, and nationality have a significant effect on their understanding of traffic signs. A quadratic term involving income had a significant negative effect. In the presence of the above variables age, marital status, drivers experience and accident experience ratio proved to be unstable. In fact, it is the drivers' personal characteristics which control the drivers' understanding abilities and not their accident involvement rates. Male drivers with over ten years of driving experience are significantly better than less experienced male drivers. Male drivers are better than female drivers in all experience categories. Single and married drivers understand the signs equally well [7].

Drivers age, education and driving experience played prominent roles in the understanding of traffic signs while marital status and age had no effect on the understanding [8].

In a study in Israel, 48 undergraduate students were tested with 30 different traffic signs. The comprehension of traffic signs between symbolic and text displays was examined. Results indicated that text signs were better comprehended and the reaction time was improved for the symbolic signs with added text, especially for less familiar signs. [9]. However, another study argued that the addition of text can only improve comprehension of signs for local drivers but in foreign settings, text traffic signs in local language would worsen driver's comprehension. In the study, the text traffic signs such as stop sign and yield sign seem to be relatively difficult to understand from tourist's perspectives [10].

Research conducted in Turkey found that many traffic signs were not well known to the drivers. Only 12 signs were identified correctly by $70 \%$ or more of the participants. Some researches further investigated individual differences in performance on comprehension test and suggested that user characteristics significantly influence comprehension [11].

The understanding of traffic signs was found be statistically related with drivers' level of education, gender, monthly income and nationality using 28 posted signs with participants from Bahrain, Kuwait, Oman, Qatar, and the United Arab 
Emirates. The findings, also show that only $56 \%$ of the posted signs could be comprehended [12].

The percentage of correct responses for all signs combined was only around 49\% - 50\% for regulatory signs, $52 \%$ for warning signs, and $55 \%$ for informatory signs. Out of the 42 signs evaluated, only four traffic signs were understood by more than 80 percent of the respondents. These signs are "No Overtaking", "No Use of Horn", "Pedestrian Crossing", and "Road Works". Twelve other signs were understood by more than $60 \%$ (but less than $80 \%$ ) of the respondents-"Roundabout", "Side Road Right", "Road Hump", Railway Level Crossing with Gate or Barrier", Stop", "No Rickshaws", "No Left Turn", "No U-Turn", One Way Traffic", "Hospital and Fire Station". Based on analyses of demographic and driving characteristics of the respondents, it would be reasonable to assume that the results of the understanding of traffic signs presented here are applicable to male professional drivers of ages between 25 and 44 years. [13]

It is believed that there is a low level of comprehension of road signs by road users in Nigeria which in turn results to increased accident rates. This study assesses the level of comprehensibility of some road signs by drivers in Kano city with the aim of proposing ways to increase the level of understanding of the road signs.

\section{METHODOLOGY COLLECTION}

AND

DATA

A questionnaire survey was used for data collection in this study. The questionnaire was distributed randomly to drivers in Kano city. A total of 190 questionnaires were administered in schools, motor parks and around parking lots of some shopping centers amongst commercial and private drivers of cars, trucks, tricycle, motorcycle, and bicycle. The questionnaire was divided into 2-sections. The first section comprises of demographic characteristics which include sex, age, level of education, type of vehicle driven, driving experience and license category (private or commercial). The second section comprises of 10-warning signs, 10- regulatory signs and 10-informatory signs making a total of 30 road signs. The signs were carefully selected to capture the most important traffic signs in the state with higher association with safety issues. Each of the signs was given a code WS1WS10 for warning signs, RS1-RS10 for regulatory signs and IS1-1S10 for informatory signs and respondents were given a multiple choice under each sign. The responses were classified as " 0 " for incorrect response and "1" for a correct response for all the signs.

Twenty (20) of the selected traffic signs were obtained from the previous studies and remaining ten (10) road signs are local signs. Ben-Bassat and Shinar have used the road Signs WS3, WS5, WS8, WS9, IS6, RS1, RS3, RS6 and RS9 in a study to test the effect of context and drivers' age on highway traffic signs comprehension [14]. The use of road signs WS1, WS10, IS1, IS2, 1S5, 1S6, RS1, RS2, RS5, RS8, and RS9 was employed in a study to study the correlation between drivers' personal characteristics and their familiarity/comprehensibility with some traffic signs [15]. Other traffic signs that were used in previous research include WS7 [9] and IS7 [16].
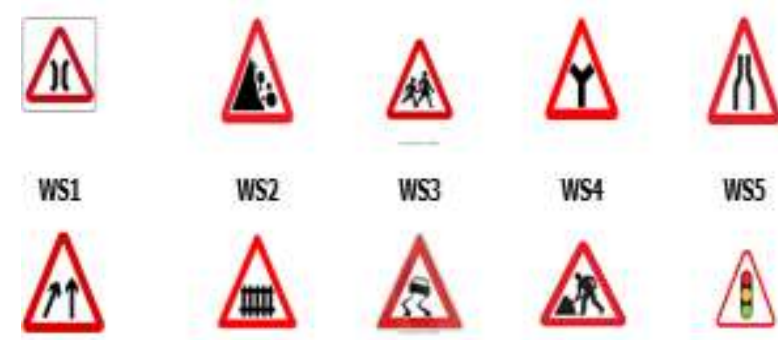
WS2

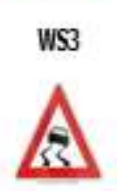

WS4 WS5
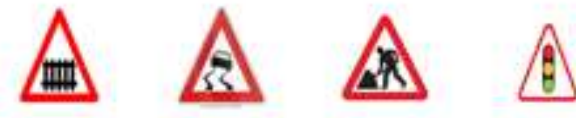

WS6

WS7

WS8

WS9

W510

Figure 1. Warning Signs.

Figure 1 shows the warning signs evaluated in the study. The signs have the following meaning: WS1 = Narrow bridge ahead, WS2 $=$ falling rock, WS3= school crossing, WS4=Y-1ntersection, WS5= Narrow road, WS6 $=$ Line merge ahead, WS7 $=$ Rail line, WS8= slippery road, WS9=Road work, WS10 $=$ traffic light. 


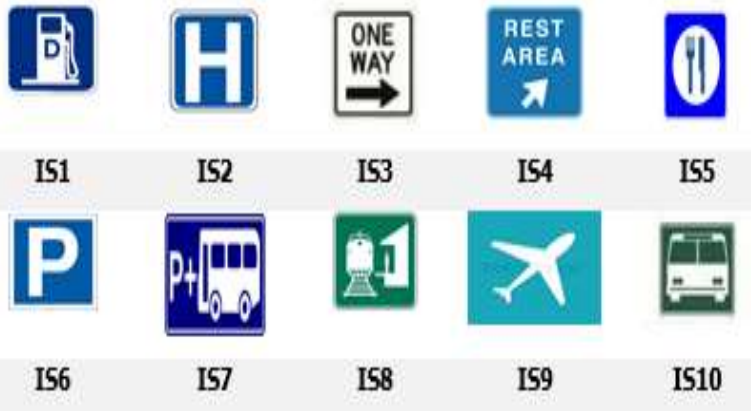

Figure 2. Informatory Signs.

Figure 2 shows the informatory signs used in the study. The meaning of the signs is IS1= Gasoline station, IS2=Hospital, IS3= one-way, IS4= rest area, IS5= Restaurant, IS6= Parking, IS7= park and ride, IS $8=$ Train station, IS9 $=$ Airport, IS $10=$ Bus station.

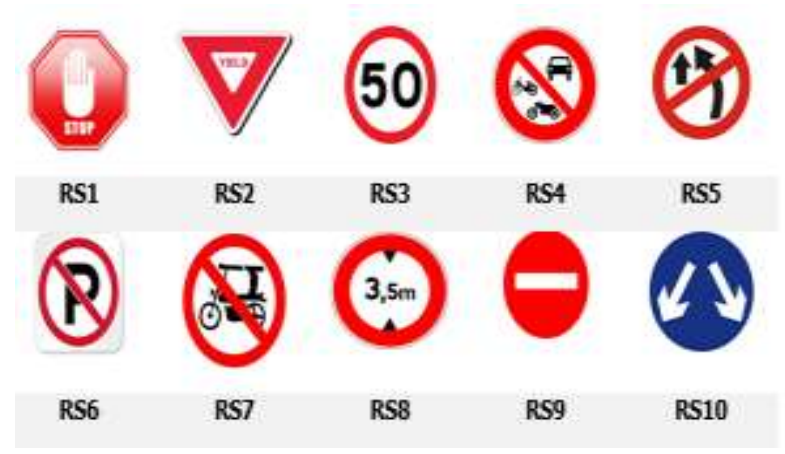

Figure 3. Regulatory signs.

The regulatory signs used were presented in figure 3 , the signs have the following meanings: RS1= stop, RS2=yield, RS3= maximum speed of 50kph, RS4 $=$ All vehicles prohibited, RS5 $=$ No overtaking, RS6 $=$ No parking, RS7 $=$ Tricycle prohibited, RS8 $=$ Height limit of $3.5 \mathrm{~m}, \mathrm{RS} 9=$ No Entry for all types of vehicles, RS10= Pass either.

\section{RESULTS AND DISCUSSIONS}

\subsection{Demographic characteristics of respondents}

Table 1 shows the demographic profile of the respondents. Majority of the respondents are male (91.6\%) which is due to the disproportionate ratio between male and female drivers in Kano city. Almost $90 \%$ of the respondents are youth below the age of 40 years showing that majority of the state drivers are young people. This is as a result of the country's population where $82 \%$ of the population were below 40-years age [17]. The educational level of the drivers shows that $37.9 \%$ have up to SSCE level, $33.7 \%$ have OND, $14.7 \%$ have BSC degree, $4.2 \%$ have MSC degrees and $8.4 \%$ have primary education and only $1.1 \%$ had an informal education. $62 \%$ of the respondents have driving experience of 5-15 years, $11.6 \%$ have over 20 years of experience. $63.2 \%$ of the respondents are private drivers and $36.8 \%$ are commercial drivers. $63.2 \%$ are Car and truck drivers which are believed to be more concerned with the road signs.

\subsection{Comprehension of road signs}

A total of 30 road signs were evaluated, the result in table 2 shows that informatory signs were more comprehended (83.2\%), followed by regulatory signs $(79.5 \%)$ then Warning signs $(74.8 \%)$. The overall comprehension of the signs is good which may be related with education level $(90 \%$ have at least to SSCE education) and experience of drivers (85.3\% at least 5 years of driving experience). The warning signs with less than $75 \%$ comprehension are $\mathrm{WS} 1=$ "Narrow bridge" $(60 \%)$, WS6= "line merge ahead" (62.1\%), WS $8=$ "slippery road" $(63.2 \%)$, WS5 = "narrow road" $(71.6 \%)$ and WS2= "falling rock" (72.6\%). Three regulatory signs have a comprehension level of less than 75\%; RS9= "No entry for all vehicles" (70.5\%), RS8= "height limit of $3.5 \mathrm{~m} "(72.6 \%)$ and RS10= "pass either" $(73.7 \%)$. Only IS7 = "park and ride" $(54.7 \%)$ has a comprehension level of less than $75 \%$ among the informatory signs evaluated and it's the least comprehended sign of all signs evaluated Only IS1 = "fuel station", RS1= "stop sign" and WS3 = "school crossing" out of the total signs evaluated were comprehended by more than $90 \%$ of the respondents. 
Table 1. Respondent's Profile.

\begin{tabular}{|c|c|c|c|}
\hline \multicolumn{4}{|c|}{ Characteristics of Respondents } \\
\hline Characteristics & & Number & Percentage \% \\
\hline \multirow{2}{*}{ Gender } & Male & 174 & 91.6 \\
\hline & Female & 16 & 8.4 \\
\hline \multirow[t]{5}{*}{ Age } & $<20$ & 14 & 7.4 \\
\hline & $20-30$ & 104 & 54.7 \\
\hline & $30-40$ & 54 & 28.4 \\
\hline & $40-50$ & 14 & 7.4 \\
\hline & $>50$ & 4 & 2.1 \\
\hline \multirow[t]{6}{*}{ Education Level } & Primary & 16 & 8.4 \\
\hline & SSCE & 72 & 37.9 \\
\hline & OND & 64 & 33.7 \\
\hline & BSc. & 28 & 14.7 \\
\hline & MSc. & 8 & 4.2 \\
\hline & Informal & 2 & 1.1 \\
\hline \multirow[t]{5}{*}{ Type of Vehicle } & Bicycle & 20 & 10.5 \\
\hline & Motorcycle & 40 & 21.1 \\
\hline & Tricycle & 10 & 5.3 \\
\hline & Car & 110 & 57.9 \\
\hline & Truck & 10 & 5.3 \\
\hline \multirow[t]{2}{*}{ Category of Licence } & Private & 120 & 63.2 \\
\hline & Commercial & 70 & 36.8 \\
\hline \multirow[t]{5}{*}{ Driving Experience } & $<5$ & 28 & 14.7 \\
\hline & $5-10$ & 68 & 35.8 \\
\hline & $11-15$ & 50 & 26.3 \\
\hline & $16-20$ & 22 & 11.6 \\
\hline & $>20$ & 22 & 11.6 \\
\hline
\end{tabular}

Table 2. Comprehension of Road Sign on Profile of Respondents.

\begin{tabular}{llc}
\hline Profile of Correspondents & & Average Comprehension (\%) \\
\hline GENDER & Male & 79.0 \\
& Female & 76.0 \\
\hline AGE & $<20$ & 76.0 \\
& $20-30$ & 81.8 \\
& $30-40$ & 78.0 \\
& $40-50$ & 65.2 \\
& $>50$ & 90.0 \\
\hline EDUCATION LEVEL & Primary & 80.0 \\
& SSCE & 77.0 \\
& OND & 80.2 \\
& BSc & 81.0 \\
& MSc & 84.2 \\
\hline TYPE OF VEHICLE & Bicycle & 78.0 \\
& Motorcycle & 82.2 \\
& Tricycle & 66.0 \\
& Car & 81.0 \\
& Truck & 65.0 \\
\hline DRIVING EXPERIENCE & $<5$ & 74.0 \\
& $5-10$ & 75.2 \\
& $11-15$ & 78.0 \\
& $16-20$ & 80.5 \\
& $>20$ & 87.0 \\
\hline
\end{tabular}




\section{CONCLUSIONS}

From the analysis of the result, it can be concluded that the comprehension level of road signs in Kano is good as the average comprehension level is $79 \%$. The least comprehended signs in Kano is "park and ride" with comprehension level of $54.7 \%$, followed by "Narrow bridge" (60\%), "line merge ahead" (62.1\%), "slippery road" (63.2\%), "No entry for all vehicles" (70.5\%). The low comprehension of the "park and ride" traffic sign is as a result of its low familiarity among the drivers since its installed in few places in the city and most of the installed signs were damaged due to road accidents or covered with posters of politicians which a common practice in the state. The "line merge ahead", "narrow bridge" and "slippery road" are mostly seen on interstate highways and only drivers that travel more often are mostly familiar with the signs and low level of comprehension of the signs may be attached to the fact that the study was conducted within the metropolis without considering that the drivers traveled out of the city or not. The signs with up to $90 \%$ recognition were "fuel station", "stop sign" and "school crossing" which corroborates with research conducted in Jordan [15]. These traffic signs are the most common and familiar to all road users due to their high frequency on the roads. The message on the signs is very clear and easy to comprehend its meaning even on seeing it for the first time.

Male drivers seem to comprehend road signs more than the female drivers. Driving experience shows a positive effect on the driver's response, drivers with over 20 years' experience comprehend $87 \%$ of all the signs as against $74 \%$ for less than 5 -years' experience. Truck drivers and tricycle drivers are the least in the signs understanding having $65 \%$ and $66 \%$ respectively while car divers comprehend up to $81 \%$ of the signs. The low comprehension level among truck drivers and tricycle users may be associated with their low education level as the majority of road users in this category hardly make it to the high school. Another factor is the manner in which driver's license are issued in Nigeria as most drivers do not undergo the required training before obtaining the license.

The relationship between a driver's level of comprehension and involvement in a traffic accident which has not been considered in this research should be studied in the future. Future research should also focus on obtaining the correlation between response time and comprehension level among various road users in Kano state. The comprehension level among the road users can be improved by sanitizing the license issue procedure in such a way that, all prospective drivers must undergo training through which they will learn a lot and be familiarized with all necessary traffic signs before been issued with a driving license.

\section{REFERENCES}

[1]. Panoiu M., Rat C. L., and Panoiu C., Study on Road Sign Recognition in Labview, in International Conference on Applied Sciences 2015 (2015) 1-10.

[2]. Bezuidenhout U., Road Sign Conspicuity And Memorability: What We See And Remember, in IPENZ Transportation Group Conference, March 2014 (2014) 1-6.

[3]. Dewar R. E., Kline D. W., and Swanson H. A., Age differences in Comprehension of Traffic Sign Symbols, J. Transp. Res. Board (TRR 1456), 1994 1-10,

[4]. Zhang T. and Chan A. H., Traffic Sign Comprehension: A Review of İnfluential Factors and Future Directions for Research, in International Multi Conference of Engineers and Computer Scientists (IMECS), 2013.

[5]. Makinde O. O. and Oluwasegunfunmi V., Comprehension of Traffic Control Devices Amongst Urban, Eur. J. Eng. Technol., 2-1 (2014) 9-19.

[6]. Munawar A. and Setiadji B. H., Drivers Comprehension of the Traffic Signs, Int. J. Sci. Res., 5-2 (2016) 534-538.

[7]. Al-madani H., Assessment of Drivers Comprehension of Traffic Signs Based on Their Traffic, Personal And Social Characteristics, Transp. Res. Part F, 5 (2002).

[8]. Makinde O. O. and Opeyemi D. A., Understanding of traffic Signs By Drivers - A Case of Akure City, Ondo State, Nigeria, 
ARPN J. Sci. Technol., 2-7 (2012) 608-612. [13]. Razzak A. and Hasan T., Motorist

[9]. Shinar D. and Vogelzang M., Comprehension of Traffic Signs With Symbolic Versus Text Displays, Transp. Res. Part F, 18 (2013) 7282.

[10]. Choocharukul K. and Sriroongvikrai K., Road Safety Awareness and Comprehension Road from International Tourist's Perspectives : A Case of Study of Thailand, in Transportation Research Procedia, 25 (2017) 4518-4528.

[11]. Kirmizioglu E. and Tuydes-Yaman H., Comprehensibility of Traffic Signs among Urban Drivers İn Turkey, Accid. Anal. Prev., 45 (2012) 131-141.

[12]. Al-Madani H. and Al-Janahi A., Assessment of Drivers Comprehension of Traffic Signs Based on their Traffic, Personal and Social Characteristic, Transp. Res. Part F, 5 (2012) Understanding of Traffic Signs : A Study in Dhaka City, J. Civ. Eng., 38-1 (2010) 17-29.

[14]. Ben-Bassat T. and Shinar D., The Effect of Context and Drivers' Age on Highway Traffic Signs Comprehension, Transp. Res. Part F Traffic Psychol. Behav., 33 (2015) 117-127.

[15]. Taamneh M. and Alkheder S., Traffic Sign Perception among Jordanian Drivers: An Evaluation Study, Transp. Policy, 66 (2018) 17-29.

[16]. Shinar D., Dewar R. E., Summala H., and Zakowska L., Traffic Sign Symbol Comprehension: A Cross-Cultural Study, Ergonomics, 46-15 (2003) 1549-1565.

[17]. National Bureau of Statistics, National Population Estimates, Abuja, Nigeria, 2016. 63-76. 